\title{
DAMPAK PANDEMIK COVID-19 TERHADAP PROFITABILITAS USAHA MIKRO KECIL MENENGAH DI KOTA MAKASSAR
}

\author{
Lisa Natalia \\ (lisanatalia6000@gmail.com)
}

Institut Bisnis dan Keuangan Nitro Makassar

JI. Prof. Abdurahman Basalamah No. 101

90231

\begin{abstract}
Abstrak
Penelitian yang saya lakukan ini bertujuan untuk melihat sejauh mana pengaruh pandemik covid-19 terhadap profitabilitas usaha mikro kecil menengah di kota makassar, Metode penelitian yang digunakan dalam penelitian ini adalah data kuantitatif yaitu data dan informasi yang diukur menggunakan laporan keuangan. Pengaruh pandemik covid19 ini membuat perekomomian yang ada di Indonesia menurun secara drastis, akibatnya 87,5 persen dari pelaku UMKM terpaksa menggulu tikar akibat pandemik, Dari jumlah ini, sekitar 93,2 persen diantaranya terdampak negatif disisi penjualan. Kemudian dari adanya pandemik membuat pelaku UMKM melakukan pembatasan karyawan dengan cara melakukan pemberhentian kerja karyawan akibat tidak mampu untuk membayar gaji karyawan karena tidak adanya pemasukan. UMKM yang mampu bertahan di kondisi saat ini yaitu UMKM yang mampu beradaptasi dengan kondisi yang ada saat ini dan mampu melakukan berbagai inovasi terbaru.
\end{abstract}


kata kunci: Dampak Pandemi Covid-19 Terhadap UMKM, Profitabilitas, Covid-19, UMKM.

\section{PENDAHULUAN}

UMKM merupakan jenis usaha yang memiliki peran penting dalam peningkatan PDB (Pendapatan Domestik Bruto) suatu negara khususnya di Indonesia Dalam Putri (2020). Covid-19 atau yang sering kita dengar dengan sebutan virus corona adalah jenis virus yang dapat menular dan menyerang system pernafasan. virus corona ini di sebabkan karena adanya infeksi pada system pernafasan yang menyebabkan kesulitan untuk bernafas, virus ini pertama kali muncul di Wuhan, Hubel, China pada tahun 2019.

Banyak upaya yang dilalukan oleh pemerintah dan masyarakat untuk pencegahan penularan covid-19 yaitu dengan menjaga jarak dan rajin mecuci tangan dengan sabun dan memperbanyak wastafel protable yang diadakan secara mandiri oleh masyarakat. Pemerintah juga melakuan Pembatasan Sosial Berskala Besar (PSBB) serta pemerintah juga menghimbau kepada masyarakat untuk stat at home (tinggal di rumah aja).

Menurut Rosita (2020) Salah satu dampak dari covid-19 adalah UMKM di Indonesia, berdasarkan data dari kementrian koperasi yang menyebutkan bahwa 1.785 koperasi dan 163.713 pelaku usaha mikro, kecil dan menengah (UMKM) terdampak pandemi covid-19. dari kebanyakan sector koperasi yang terdampak yakni pada sector makanan dan minuman. Kasus covid-19 ini berdampak bagi perekonomian masyarakat, sehingga kebanyakan dari sector usaha yang terpaksa melakukan PHK besar-besaran terhadap karyawannya di karnakan usaha yang dijalannya mengalami kendala finansial. 
Menurut Putri (2020) Kementrian koperasi dan UMKM mengatakan bahwa koperasi yang bergerak pada bidang jasa dan produksi juga terdampak pada pandemi. Para pengusaha meresahkan turunnya penjualan, kekurangan modal, dan terhambatnya distribusi. sehingga sedikitnya 39,9 persen para UMKM memutusan mengurangi stok barang selama pembatasan sosial berskala besar (PSBB) akibat covid-19. Sementara itu 16,1 persen UMKM memilih mengurangi karyawan akibat toko fisik di tutup.

Di Indonesia sendiri UMKM memiliki kontribusi maupun peranan yang cukup besar yaitu dengan membuka lapangan pekerjaan sehingga kesempatan bagi masyarakat untuk berpenghasilan untuk memenuhi kebutuhan hidupnya.

Dampak yang signifikan yang dapat kita lihat terhadap perekonomian di Indonesia. Di semua lini mikro, kecil hingga koperasi terdampak dengan adanya wabah covid-19. Penjualan menurun, permodalan, pesanan menurun, kesulitan bahan baku, dan kredit macet dalam sekejap ekonomi tiba-tiba ambruk.

Banyak sector UMKM yang terguncang akibat pandemi covid-19 bukan hanya bagi pengusaha makanan dan minuman tetapi industri pertanian juga berdampak sehingga banyak dari industi tersebut berhenti beroperasi baik itu sementara ataupun permanen karena laba yang mereka peroleh menurun drastis.

Menurut Daga dan Wahyuni (2021) Risiko konsumen ini yang membuat pelaku UMK terhambat dalam penerapan e-commerce, jika konsumen menginginkan pengiriman barang yang cepat maka konsumen akan berahli ke perusahaan yang lain tanpa harus mengeluarkan biaya tambahan untuk mendapatkan produk tersebut dengan waktu yang cepat. Selain variabel tersebut yang menghambat penggunaan e-commerce 
pada UMK di kota Makassar ada variabel lain yang tidak kalah penting dalam penerpan tersebut yaitu variabel keamanan transaksi, kendala infrastruktur dan akses internet menjadi point yang diperhatikan oleh UMK.

\section{RUMUSAN MASALAH}

Dari latar belakang penilitian diatas maka penulis merumuskan permasalahan yang diteliti yaitu "Bagaimana tingkat rasio profitabilitas UMKM dikota makassar dimasa pandemic covid-19?".

\section{TUJUAN PENELITIAN}

Adapu tujuan dari penelitian yang saya lakukan yaitu untuk mengukur tingkat rasio profitabilitas UMKM di kota makassar di masa pandemik covid-19.

\section{TINJAUAN PUSTAKA}

Menurut UUD 1945 kemuadian dikuatkan melalui TAP MPRNO.XVI/ MPR RI /1998 tentang Politik Ekonomi dalam rangka Demokrasi Ekonomi, Usaha Mikro, Kecil, dan Menengah perlu diberdayakan sebagai bagian integral ekonomi rakyat yang mempunyai kedudukan, peran, dan potensi strategis untuk mewujudkan struktur perekonomian nasional yang makin seimbang, berkembang, dan berkeadilan. Selanjutnya dibuatklah pengertian UMKM melalui UU No.9 Tahun 1999 dan karena keadaan perkembangan yang semakin dinamis dirubah ke Undang-Undang No.20 Pasal 1 Tahun 2008 tentang Usaha Mikro, Kecil dan Menengah maka pengertian UMKM adalah sebagai berikut: 
1) Usaha Mikro adalah usaha produk tifmilik orang perorangan dan/ atau badan usaha perorangan yang memenuhi kriteria Usaha Mikrose bagaimana diatur dalam Undang-Undang ini.

2) Usaha Kecil adalah usaha ekonomi produktif yang berdiri sendiri, yang dilakukan oleh orang perorangan atau badan usaha yang bukan merupakan anak perusahaan atau bukan cabang perusahaan yang dimiliki, dikuasai, atau menjadi bagian baik langsung maupun tidak langsung dari Usaha Menengah atau Usaha Besar yang memenuhi kriteria Usaha Kecil sebagai mana dimaksud dalam Undang-Undang ini.

3) Usaha Menengah adalah usaha ekonomi produktif yang berdiri sendiri, yang dilakukan oleh orang perorangan atau badan usaha yang bukan merupakan anak perusahaan atau cabang perusahaan yang dimiliki, dikuasai, atau menjadi bagian baik angsung maupun tidak langsung dengan Usaha Kecil atau Usaha Besar dengan jumlah kekayaan bersih atau hasil penjualan tahunan sebagai mana diatur dalam Undang- Undang ini.

4) Usaha Besar adalah usaha ekonomi produktif yang dilakukan oleh badan usaha dengan jumlah kekayaan bersih atau hasil penjualan tahunan lebih besar dari Usaha Menengah, yang meliputi usaha nasional milik negara atau swasta, usaha patungan, dan usaha asing yang melakukankegiatan ekonomi di Indonesia.

5) Dunia Usaha adalah Usaha Mikro, UsahaKecil, Usaha Menengah, dan Usaha Besar yang melakukan kegiatan ekonomi di Indonesia dan berdomisili di Indonesia. 
Menurut Daga dan taufiq (2018) Perilaku konsumen adalah segala sesuatu yang mempengaruhi seseorang dalam memutuskan suatu hal, perilaku ini dipengaruhi oleh faktor-faktor yang bersifat internal dan ekstemal. Faktor internal adalah faktor yang timbul dari dalam konsumen itu sendiri yang meliputi usia konsumen, pekerjaan konsumen, keadaan ekonomi konsumen, gaya hidup seseorang, motivasi dalam menggunakan sesuatu, persepsi terhadap suatu produk, kepercayaan dan sikap konsumen terhadap produk yang dibeli. Sedangkan faktor ekstemal adatah faktor yang mendorong seseorang dari luar konsumen itu sendiri, yaitu kebudayaan seseorang, kelas sosial konsumen, faktor yang mempengaruhi diluar keluarganya yaitu referensi dari atasan atau teman

Tabel 2.1

Kriteria UMKM dan usaha besar berdasarkan Asset dan Omsetnya

\begin{tabular}{|c|c|c|}
\hline \multirow{2}{*}{ Ukuran Usaha } & \multicolumn{2}{|c|}{ Kriteria } \\
\cline { 2 - 3 } & Asset & Omset \\
\hline Usaha Mikro & Maksimal Rp 50 juta & Maksimal Rp 300 juta \\
\hline Usaha Kecil & $>$ Rp 50 juta - Rp 500 juta & $>$ Rp 300 juta - Rp 2,5 miliar \\
\hline Usaha Menengah & $>$ Rp 500 juta -Rp 10 miliar & $>$ Rp 2,5 miliar- Rp 50 miliar \\
\hline Usaha besar & >Rp 10 miliar & $>$ Rp 50 miliar \\
\hline
\end{tabular}




\section{PROFITABILITAS}

Profitabilitas adalah kemampuan suatu perusahaan untuk menghasilkan laba selama suatu periode tertentu. Terdapat beberapa rasio keuangan yang umumnya dipergunakan untuk menilai tingkat profitabilitas suatu perusahaan, seperti Gross Profit Margin, Net Profit Margin, Return on Assets (ROA), dan Return on Equity (ROE). Indikator yang digunakan penulis untuk mengetahui tingkat profitabilitas perusahaan dalam penelitian ini adalah Return on Assets (ROA) Dalam (Yusnita dan Fitriadi, 2019). Mendefinisikan profitabilitas sebagai kemampuan perseroan untuk memperoleh laba dan potensi untuk memperoleh penghasilan pada masa yang akan datang yang dapat diukur dengan Return on Equity (ROE) dan Return on Assets (ROA).

Rasio yang termasuk rasio profitabilitas antara lain:

> Gross Profit Margin (Margin Laba Kotor)

$>\quad$ Net Profit Margin (Margin Laba Bersih)

$>$ Rentabilitas Ekonomi/ Daya Laba Besar/ Basic Earning Power

$>$ Return On Investment (ROI)

$>$ Return On Equity (ROE)

$>$ Earning Per Share ( EPS)

\section{PANDEMI COVID-19}

Pandemi COVID-19 bukan hanya terjadi di Indonesia, tetapi sudah mendunia. Timbul-nya kecemasan akan tertularnya virus COVID-19, menyebabkan pemerintah mengambil keputusan tegas, untuk mengutamakan kesehatan dengan melakukan Pembatasan Sosial Berskala Besar (PSBB). 
Menurut IImiya dalam (Amri, 2020), COVID-19 merupakan penyakit menular yang disebabkan oleh sindrom pernapasan akut corona virus 2 (severeacute respiratory syndrome coronavirus 2 atau SARS-CoV-2) Virus ini merupakan keluarga besar Corona virus yang dapat menyerang hewan. Ketika menyerang manusia, Coronavirus biasanya menyebabkan penyakit infeksi saluran pernafasan, seperti flu, MERS (Middle East Respiratory Syndrome), dan SARS (Severe Acute Respiratory Syndrome). COVID-19 sendiri merupakan coronavirus jenis baru yang ditemukan di Wuhan, Hubei, China pada tahun 2019 Dalam (Supeno dan Hendarsih, 2020).

\section{METODE PENELITIAN}

Jenis data yang di gunakan dalam penelitian ini berupa data kuantitatif, yaitu data dan informasi yang diukur menggunakan laporan keuangan UMKM tahun 2019-2021. Sumber data yang digunakan yaitu data sekunder berupa angka dari laporan keuangan dari UMKM dan juga di peroleh dari beberapa jurnal yang berkaitan dengan judul penulis. Penelitian ini menggunakan dua teknik pengumpulan data berupa penelitian dokumentasi yaitu pengumpulan data yang dilakukan dengan cara mencari data mengenai varibel yang di teliti, yaitu mengumulkan laporan keuangan dan dokumentasi-dokumentasi yang berkaitan penelitian. dan penelitian pustaka dimana metode penelitian yang digunakan yaitu dengan cara mengumpulkan informasi yang diperoleh dari jurnal dan referensi buku yang berkaiatan dengan penelitian.

\section{PENUTUP}

Berdasarkan hasil penelitian, Maka dapat di simpulkan sebagai berikut : 
UMKM merupakan jenis usaha yang memiliki peran penting dalam peningkatan PDB suatu negara khususnya di Indonesia. virus corona ini di sebabkan karena adanya infeksi pada system pernafasan yang menyebabkan kesulitan untuk bernafas, virus ini pertama kali muncul di Wuhan, Hubel, China pada tahun 2019. Menurut Rosita Salah satu dampak dari covid-19 adalah UMKM di Indonesia, berdasarkan data dari kementrian koperasi yang menyebutkan bahwa 1.785 koperasi dan 163.713 pelaku usaha mikro, kecil dan menengah terdampak pandemi covid-19. dari kebanyakan sector koperasi yang terdampak yakni pada sector makanan dan minuman.

Di Indonesia sendiri UMKM memiliki kontribusi maupun peranan yang cukup besar yaitu dengan membuka lapangan pekerjaan sehingga kesempatan bagi masyarakat untuk berpenghasilan untuk memenuhi kebutuhan hidupnya. Dampak yang signifikan yang dapat kita lihat terhadap perekonomian di Indonesia. Di semua lini mikro, kecil hingga koperasi terdampak dengan adanya wabah covid19. Penjualan menurun, permodalan, pesanan menurun, kesulitan bahan baku, dan kredit macet dalam sekejap ekonomi tiba-tiba ambruk.

Gross Profit Margin merupakan persentase laba kotor dibandingkan dengan seles. Operating Profit Margin merupakan perbandingan antara laba rugi usaha dan penjualan. Return on investment merupakan rasio yang menunjukan berapa besar laba bersih di peroleh perusahaan bila di ukur dari nilai aktiva. Return on equity merupakan perbandingan antara laba bersih sesudah pajak dengan total ekuitas. Earning per share adalah rasio yang menunjukan berapa besar kemungkinan perlembar saham yang akan menghasilkan laba. Earning per share merupakan rasio yang menggambarkan jumlah rupiah yng diperoleh untuk setiap lembar saha biasa Dalam. Oleh karena itu pada 
umumnya menajemen perusahaan, pemegang saham biasa dan calon pemegang saham sangat teretarik akan earning per share. Earning per share adalah suatu indicator keberhasilan perrusahaan.

\section{REFERENSI}

Daga, R., Maddatuang, B., \& Wahyuni, R. (2021). Faktor-Faktor Penghambat Penggunaan E-Commerce pada Usaha Mikro Kecil di Kota Makassar. YUME: Journal of Management, 3(3), 115-127.

Daga, R., \& Taufiq, H. I. (2018). Persepsi Pengusaha Mikro Terhadap Lembaga Keuangan Mikro di Makassar.

Suci, Y. R. (2017). Perkembangan UMKM (Usaha mikro kecil dan menengah) di Indonesia. Cano Ekonomos, 6(1), 51-58.

Supeno, W., \& Hendarsih, I. (2020). KINERJA KREDIT TERHADAP PROFITABILITAS BPR PADA MASA PANDEMI COVID-19. Jurnal Akrab Juara, 5(4), 147-161.

Tiawon, H., \& Kristinae, V. (2021). AKTIVITAS EKONOMI UKM DALAM RANGKA MENJAGA KETAHANAN PANGAN MASA PANDEMIC COVID-19 DI KALIMANTAN TENGAH. MEDIA BINA ILMIAH, 15(9), 5129-5138.

Umami, A. K. (2017). Pengaruh faktor finansial terhadap profitabilitas usaha mikro, kecil dan menengah (UMKM) penerima pembiayaan Lembaga Keuangan Syariah di Kota Malang (Doctoral dissertation, Universitas Islam Negeri Maulana Malik Ibrahim).

Yusnita, R. T., \& Fitriadi, B. W. (2019). Analisis Pengaruh Struktur Modal Terhadap Profitabilitas UMKM di Kota Tasikmalaya. Jurnal Ekonomi, Bisnis, dan Akuntansi, 21(2). 
